DOI: https://doi.org/10.34069/AI/2021.39.03.16

\title{
Perceive of organic products by Ukrainian consumers and problems of shaping market demand
}

\section{СПРИЙНЯТТЯ ОРГАНІЧНОЇ ПРОДУКЦІЇ УКРАЇНСЬКИМИ СПОЖИВАЧАМИ ТА ПРОБЛЕМИ ФОРМУВАННЯ РИНКОВОГО ПОПИТУ}

Received: March 29, 2021

\begin{abstract}
Organic production is a decisive factor in preserving the natural wealth and fertility of soils, a source of food security.

The market demand formation depends on the organic products perception and consumer preferences of potential buyers. Potential organic production research questions in Ukraine with an estimation of buyers consumption readiness of production are actual. These problens raise issues that need to be addressed. The reseafch evaluates the Ukrainian organic market development, identifies current trends in organic production with its capabilities in domestic and foreign markets, assesses the main donors of organic movement for the country, reveals the consumer demand formation for products through analysis of main motives and incentives, the organic products perception level by Ukrainian consumers and the influence strength on the demand formation. The methodological approach substantiates the selected problems of product consumption and ways to solve them through the economic and management theories
\end{abstract}

Accepted: April 29, 2021

\author{
Written by: \\ Iryna Kolokolchykova ${ }^{57}$ \\ https://orcid.org/0000-0002-5692-0901 \\ Roman Oleksenko ${ }^{58}$ \\ https://orcid.org/0000-0002-2171-514X \\ Nina Rybalchenko ${ }^{59}$ \\ https://orcid.org/0000-0003-3358-2249 \\ Liudmyla Yefimenko ${ }^{60}$ \\ https://orcid.org/0000-0002-4267-3495 \\ Ganna Ortina ${ }^{61}$ \\ https://orcid.org/0000-0001-6244-5759
}

\footnotetext{
${ }^{57}$ Department of Business Consulting and International Tourism Dmytro Motornyi Tavria State Agrotechnological University, Melitopol, Ukraine.

${ }^{58}$ Department of Public Administration, Administrative Law, Dmytro Motornyi Tavria State Agrotechnological University, Melitopol, Ukraine.

${ }^{59}$ Department of Public Administration, Administrative Law Dmytro Motornyi Tavria State Agrotechnological University, Melitopol, Ukraine.

${ }^{60}$ Department of Public Administration, Administrative Law Dmytro Motornyi Tavria State Agrotechnological University, Melitopol, Ukraine.

${ }^{61}$ Department of Public Administration, Administrative Law Dmytro Motornyi Tavria State Agrotechnological University, Melitopol, Ukraine.
} 
applications, dialectical method, abstract method - logical analysis, critical thinking, systematization and formalization method, survey, expert assessments, method of logical analysis, forecasting. The methods application allowed assessing the organic products market and its operators, to identify segments, to model their behavior with an emphasis on strengthening consumer motivation. The research effectiveness is to find ways to strengthen the market demand formation for organic products within the country and its position in international markets, reduce production risks and address the perception of organic products.

Keywords: organic products, organic market, consumers, healthy lifestyles, agricultural production. обгрунтовує виділені проблеми споживання продукції та шляхи їх вирішення через застосування положень економічної теорії та теорії управління, діалектичного методу, методу абстрактно - логічного аналізу, критичного мислення, методу систематизації та формалізації, опитування, експертних оцінок, методу логічного аналізу, прогнозування. Застосування методів дозволило оцінити ринок органічної продукції та іï операторів, виділити сегменти, змоделювати їх поведінку 3 акцентом на посилення купівельної мотивації. Результативність дослідження полягає у пошуку напрямів посилення формування ринкового попиту на органічну продукції всередині країні та позиціювання іiі на міжнародних ринках, зменшення ризиків виробництва та вирішення питань сприйняття органічного продукту.

Ключові слова: органічна продукція, органічний ринок, споживачі, здоровий спосіб життя, агровиробництво.

\section{Introduction}

Research lies in the special sense of organic agricultural production for the development of the market and this segment. Organic production is becoming a trend of today in the consumption of healthy food and, as a result of healthy lifestyles. Along with producers, buyers (potential consumers) of products is the driving force and the lever for the development of the organic segment, defining the strategic guidelines. People's perception of any product is an important element in the formation of market demand. The realities of today show existing trends of increasing consumer commitment to organic products around the world. People tend to a culture of consumption of organic products, as they believe that it is useful and healthier than traditionally grown. Therefore, along with the organic market development in Ukraine, the perception of consumers of this segment is the key to creating a high demand for it and sufficient cash flow for the business. Marketing aspects of the organic products positioning is the basis for the development of this organic segment.

The processes of formation of market supply and demand, which are determined depending on the number of organic market operators, the size of agricultural land with organic and transitional status and the level of perception of the products by potential consumers, their motivational mechanisms that stimulate the process of the purchase of products.
The organic agricultural production process and consumer behavior of the organic segment in Ukraine and its regions are analyzed.

\section{Theoretical Framework}

World icientists world research various aspects of organic production, organic product, segmentation and positioning in domestic and foreign markets. Research the organic production development problems is divided into separate areas. Such scientists as Shkuratov A., Chudovska V., Vdovychenko A.; Kaminska A.; Maruszewski G., \& Hickman D.; Willer H., Lernoud J., Schlatter B., Travnicek J., Kemper L. explore the world experience of organic agriculture and its economic imperatives. Granovska, V. in her papers defines the role of organic production for Ukraine, outlines prospects. The potential, advantages and economic efficiency of Ukrainian organic products are proved by the results of scientific research Ostapenko R., Gerasimenko Y., Nitsenko V., Kolyadenko S., Balesentis T., and Streimikiene; Ponomarev S.; Pyrozhok O. The state support direction of the organic sector and species This support is found in the works of Milovanov E.; Turyansky A., Merenkov I., Dobrunova A., Prostenko A., and Oliva L. The work concerns the issues of stimulating and motivating peasants to organic production. Features of organic products consumption are 
revealed in the papers of Abrar M., Baig S., Bashir M., Shabbir R., \& Ayub M.; Mowen J., Minor M.; Blackwell R., Miniard P., J. Engel J. However, it has a more general universal approach to the perception of such products. Therefore, in our opinion, the scientific search should be narrowed to study the perception of organic products by Ukrainian consumers, assess their level of readiness to buy and identify those incentives and motives that accelerate the demand formation for products in this segment. It is this area has not found such a scientific spread, has attracted our attention and became the main task of scientific research.

\section{Methodology}

Research methodology of the organic products consumer behavior includes methodological approaches to the perception of the problem, identifying the general and individual characteristics of market participants through the set approaches and scientific knowledge methods systematization. The special organic product characteristics lead to conclusions about the cognition of consumer behavior and determines the methodological approaches choice to its measurement and evaluation. The consumer behavior research in the organic products market requires the use of analytical rather than economic methods. The methodological approach to the analysis integrity of the researched problem is realized at three levels: first, through the fundamental provisions of economic theory use and management theory, namely the dialectical method, the method of abstract - logical analysis and critical thinking in the process of the organic market systems researching of its operators interaction, internal structure formation, conceptual priorities of the formed segments; secondly, through systematization and formalization methods, surveys and expert assessments - in the consumer behavior research in the perception and decision to purchase organic products in the Ukrainian and foreign markets; thirdly, logical analysis method and forecasting - in the predicting consumer behavior process in the market, determining priorities and possible behavior when changing the influence of certain factors that shape the product perception.

The dialectical method and the method of abstract use - logical analysis and critical thinking is a tool for assessing trends in the Ukrainian organic products market; the main players identification in this market, their role in the development of this segment, the importance of each market player; critical assessment of the products perception by end users; highlighting the special demand product perception issue. Analysis and logical conclusions provide grounds for further research identifying areas, strengths and weaknesses, threats and opportunities analysis, finding alternative solutions.

Quality perception of organic products assessment by Ukrainian consumers is carried out using the comparative analysis methods, grouping and survey. Consumer behavior qualitative assessment methods research in the relevant market are justified when using tools: observation, in-depth interview, panel research, focus group opinion assessment. Projection and expert methods, perception and consumer behavior in the market are evaluating the empirical experience methods. The main tools for assessing consumer behavior and the desired response formation are the single and multiple requests methods, reciprocity, commitment, typical behavior (Blackwell, Miniard, Engel, 2007). Respondents' answers qualitative assessment is a clear vector of manufacturers actions towards the marketing product improvement, sales and communication policy. To compare the Ukrainian organic perception and exported productswe use research methods of the consumers attitude to different goods brands, namely a method based on quantitative assessment of factors influencing behavioral choice (Fishbein and Rosenberg method) and the Ideal Point method. These approaches are laid down in the of open-ended questions questionnaire formation. The use of composite and composite approaches makes it possible to identify those organic product key characteristics that lead to the purchase decision (Mowen, Minor, 1998).

Research consumer behavior continuity justifies the use logical analysis and forecasting method. The consumer research in the market logic is determined by factors that are target factors, levers and indicators that influence the decision to purchase an organic product. Preliminary methods of critical thinking, systematization and formalization are the basis for identifying influencing factors and assessing their importance. The survey method effectiveness divides the questions as influence factors by importance, thus giving them a quantitative assessment (the percentage of respondents). The responses number and the evaluation level highlight the target factors influencing the behavior of all market participants in organic 
products. This in turn provides grounds for assessing the level of cognitive consumer behavior in the market and is the basis for further research using economic methods mathematical modeling and forecasting.

Results and Discussion. Development of the organic market in Ukraine is a priority direction of modern production and the consumer demand around the world. Consumer priorities, which are formed in the organic products stimulate producers to enter the international markets, bringing up the culture of consumption of these products in Ukraine.

1. Formation and development of the organic products segment has a reasonable basis, such as favorable natural and climatic conditions, implementation of organic production technologies and organic products, the existing demand for such products (Shkuratov, Chudovska, Vdovichenko, 2015). Significant economic, environmental and social effect is manifested in the rational use of resources, land use ecologization and restoration of the agro-ecosystem, to ensure food security of the state, increasing entrepreneurial initiative among farmers, to reduce morbidity in society and sustainable rural development. But despite the significant potential and prospects for the development of organic agriculture in Ukraine, there is still no clear state policy to support producers of this segment, there is no statistical reporting, which complicates the research development, not enough high buyers willingness to purchase and consume exactly Ukrainian organic products. The main obstacle to the introduction of modern environmental technologies in agricultural production and the greening of agriculture is the lack of developed environmental legislation (Turyansky, Merenkov, Dobrunova, Prostenko, \& Oliva, 2018). The main obstacle for the development of the industry is an insufficient legal framework. Act of Ukraine «About the production and turnover of organic agricultural products and raw materials» (Act of Ukraine № 425-VII, 2013) but it still remains unimplemented. (Maruszewski, Hickman, 2017). And in the conditions that the development of any market is only possible with the effective producers interaction that form the market offer and buyers who create market demand, in Ukraine today there are trends that indicate a lack of motivation of the buyers (buyers and consumers). And without this chain and stimulation of demand, the development of the organic market is impossible.

2. Organic market in Ukraine: current trends in production

Ukraine is one of the twenty countries in the world on the area of organic farmland. However, by the volume of domestic consumption of organic products ranks only twenty-fifth in Europe (Kaminska, 2020). The development of organic production promotes the restoration of natural soil fertility, improving the quality of agricultural land, reducing environmental emissions, reducing the use of artificial chemicals and the expenditure of non-renewable energy resources, thus providing a positive impact on the environment and the environmental situation in the country, providing the consumer market with healthy and quality products, strengthening the export potential of the state, to ensure the country's food security (Milovanov, 2018).

In recent years, Ukraine has been an important supplier of organic products to European markets. The main organic products exported from Ukraine are cereals, oilseeds and legumes, wild berries, mushrooms, nuts and medicinal herbs, honey (Willer, Lernoud, 2019).

Official IFOAM statistical surveys confirm that while in 2002 there were 31 farms registered in Ukraine. Ukraine was registered 31 farms, which received the status of «organic», in 2020 there were 510 organic farms, and the total area of agricultural land in which organic production is conducted, amounted to 429100 ha [IFOAM]. Most Ukrainian organic farms are located in Kiev, Odessa, Kherson, Poltava, Vinnytsia, Zakarpattya, Lviv and Zhytomyr regions. Ukrainian certified organic farms are of different size - from several hectares to several thousand hectares of agricultural land. (Federation of Organic Movement in Ukraine, 2020) Taking into account the growing number of small organic farms, their specialisation is mainly focused on cultivation of fruit, vegetables and berries. However, the fact remains the export orientation of producers, especially leguminous crops and berries. During the last few years Ukraine has become an important supplier of organic products to Western markets. It is mainly the export of organic raw materials - cereals, oilseeds and legumes, berries, mushrooms, nuts and medicinal herbs. Rarely on the shelves of European stores can be found ready-made Ukrainian products. (Pyrozhok, 2019) 
Ukraine ranks 11th among European countries by the total area of agricultural land certified as organic. But at the same time organic land occupies less than $1 \%$ of 42700000 . Hectares of agricultural land in Ukraine. As of 2019, the total area of agricultural land with organic status was about 468 thousand hectares $(1.1 \%$ of the total area of agricultural land in Ukraine). At the same time there were 617 operators of the organic market, of which 470 - agricultural producers, Figure 1. (Information and analytical portal of the agroindustrial complex of Ukraine, 2021)

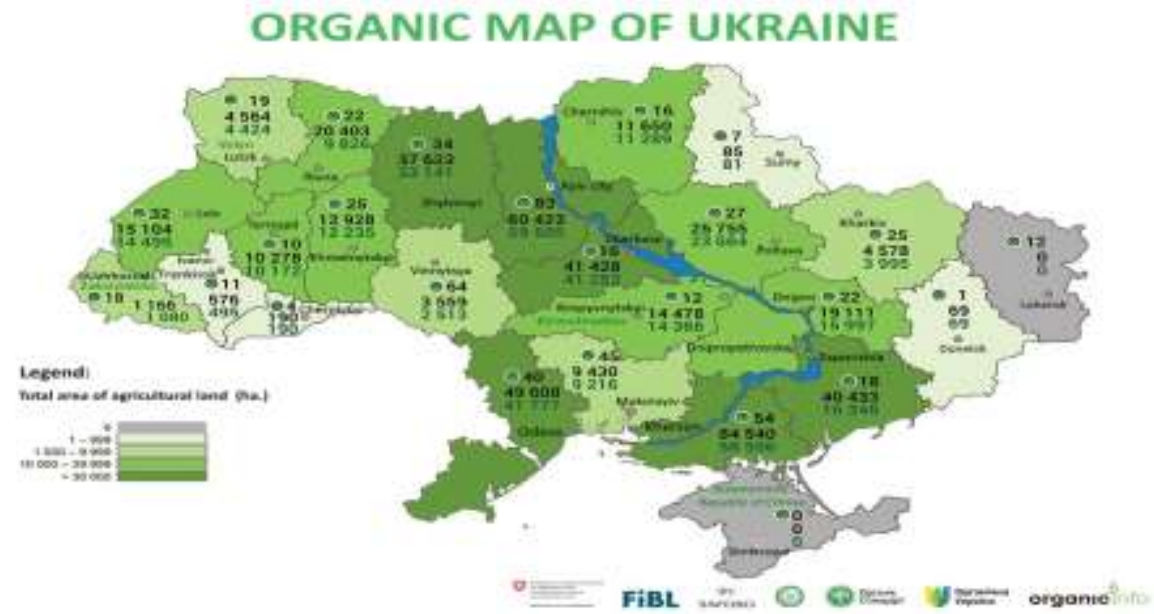

Figure 1. Organic map of Ukraine, as of 2019 (Federation of Organic Movement in Ukraine, 2020)

The main consumers of organic products are produced in the EU. In 2019 Ukraine took the 2nd place out of 123 countries in terms of imports of organic products, moving up two steps compared to the previous year.

Thus, during 2019 in the EU imported 3.24 million tons of organic agri-food products, more than $10 \%$ of which is Ukrainian. At the same time Ukrainian imports to the EU increased by $27 \%$ from 265.8 thousand tons in 2018 to 337.9 thousand tons in 2019 (Government Portal, 2020).

In the world, organic agricultural production is growing slower than the demand for organic agricultural products. This opens up good growth prospects for Ukrainian organic Agroexport (Ponomarev, 2019). The largest consumer countries of domestic organic products are the Netherlands, Germany, Switzerland, Italy, UK, Austria, Poland, Czech Republic, France, Hungary, Romania, Belgium, Bulgaria, Lithuania, Canada, Denmark, USA and Australia (Willer, H., Lernoud, J., Kemper, L., 2018). The main export products are cereals, oilseeds, berries, mushrooms, nuts, fruits and honey.

Top 10 countries-importers of Ukrainian organic products (Hot Agricultural Policy, 2020)

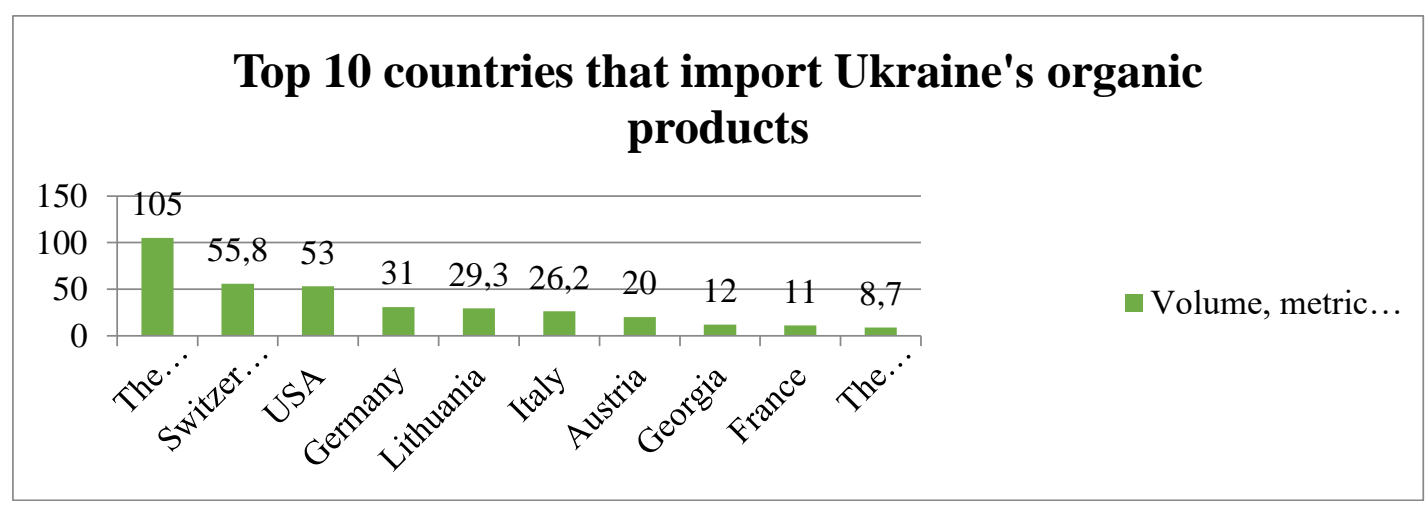

Figure 2. Top - 10 countries that import Ukrainian organic products (Ostapenko, Herasymenko, Nitsenko, Koliadenko, Balezentis, \& Streimikiene, 2020). 
1. In different years for the successful organic business, Ukraine receives international support from donor countries in support of the organic market among the major donors (Hot Agricultural Policy, 2020):

2. Switzerland: Swiss State Secretariat for Economic Affairs (SECO) Swiss Agency for Development and Cooperation (SDC).

3. Germany: Federal Ministry of Food and Agriculture (BMEL) Agriculture \& Finance Consultants (AFC) IAK Agrar Consulting since 2016.

4. U.S. Agency for International Development (USAID) Western NIS Enterprise Fund (WNISEF).

5. Canada: Minister of Foreign Affairs of Canad; Mennonite Economic Development Association (MEDA).

6. Food and Agriculture Organization (FAO) EU4Business; European Bank for Reconstruction and Development (EBRD).

In general, as of June 2019, support for organic producers in one way or another is implemented in 12 regions of Ukraine (Volyn, Zhytomyr, Zakarpattia, Kirovograd, Lviv, Odessa, Poltava, Sumy, Khmelnitsky, Cherkasy, Chernivtsi, Chernigov regions). Besides, in three more regions (Donetsk, Zaporizhzhia, Rivne regions) such support is also planned in the project documents for the nearest period. In Vinnitsa, Dnipropetrovsk, Ivano-Frankivsk, Kyiv,
Luhansk, Mykolayiv, Ternopil, Kharkiv and Kherson regions, work to identify opportunities for systematic support of organic producers is in its initial stages and is discussed by local experts of the agricultural sector (Kaminska, 2020).

Thus, the formation of market supply is taking place in a capacity-building conditions of its producers and the international donor support. And, with the strengthening of state support in the form of targeted assistance, the supply size will only increase. 3. Motives and incentives of Ukrainian organic
product potential consumers

The current state of the world food markets shows a great consumer interest in a healthy and wholesome diet along with the natural environment preservation. (Granovska, 2017) The growing demand for organic products is one of the strategic directions of agricultural development in most countries of the world. Organic food is food that is produced in compliance with certain environmental standards at all stages of the technological and distribution chain without flavorings, dyes, preservatives and genetically modified organisms with maximum preservation of their nutrients. Packaging materials for these products must be made from organic raw materials. (Willer, Lernoud, Schlatter, Travnicek, Kemper, 2020).
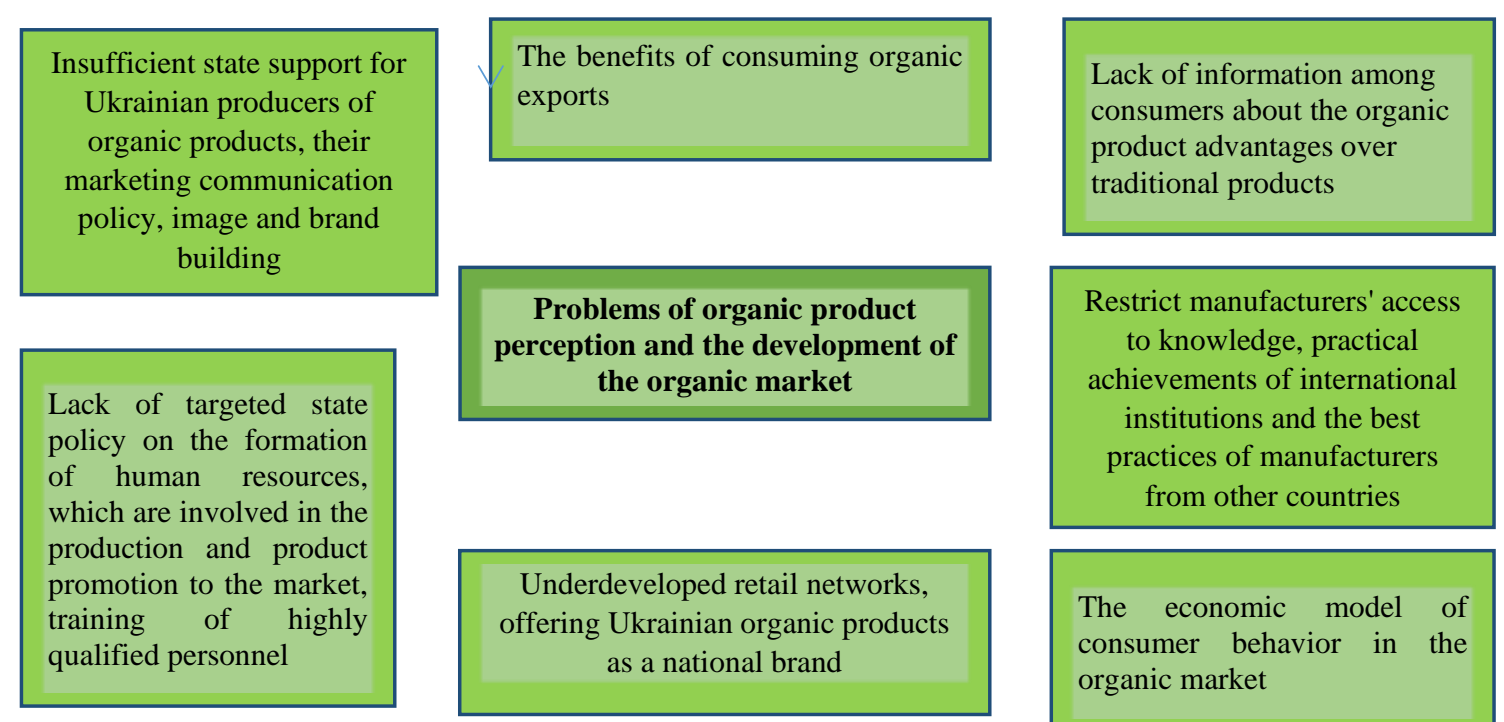

Figure 3. Problems of organic product perception by Ukrainian consumers (Developed by the author)

Ukrainian positioning of organic products at the level of the state and its regions is poorly developed. A great influence is felt on the export products of this segment. Expanding the boundaries of domestic and foreign markets for organic products should be carried out only in the introduction of motivational mechanisms for the product perception, the definition of directions and aspects of positioning. Conducted research on the Ukrainian organic product perception
Restrict manufacturers' access to knowledge, practical achievements of international institutions and the best practices of manufacturers from other countries

The economic model of consumer behavior in the organic market 
gave reasons to identify the problems that constrain the positioning process, namely (Fig. 3).

The highest consumption of organic products is in the countries with the highest incomes. In these countries the market is growing annually by $10-15 \%$. At the same time, developed countries are increasing the production of organic products every year. Since the demand for organic products does not depend on the size of the purse, but on the awareness of the actions taken (Oleksenko, Kolokolchykova, Syzonenko, 2019). In Ukraine, the consumption of organic products is constrained by the economic model of consumer behavior, which is based on the approach of benefits in zinnia. It means that the consumer pays attention only to the price, which for organic products is higher than for traditional products, and, therefore, more often refuses the products. The problem is that in the buyer's mind, the benefits of the organic product's qualitative characteristics do not prevail over the cost evaluation indicators. These and other factors that keep Ukrainian consumers from buying organic products, confirm the research on the perception of such a product, conducted during 2018 - 2019 by the survey method. The findings of the study reveal that Health Consciousness, consumer knowledge, environmental concern and personal norms had a positive relationship with consumer attitude. (Abrar, Baig, Bashir, Shabbir, \& Ayub, 2018) This research results are disclosed in the following, Figure 4.

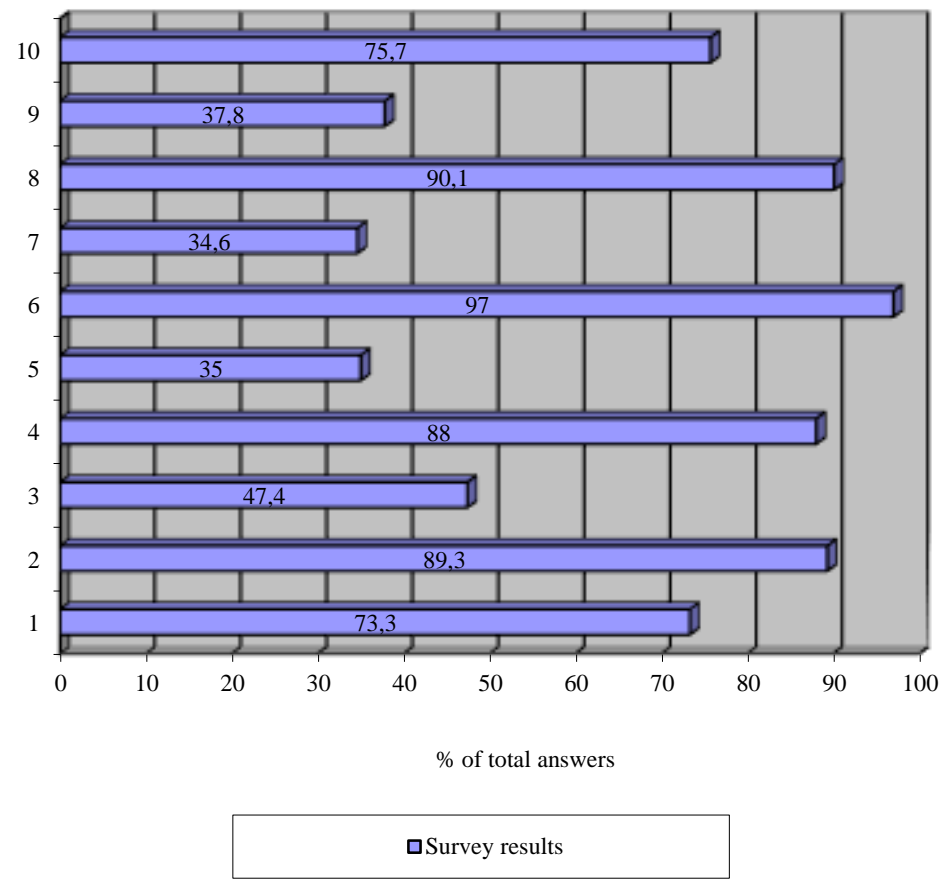

Figure 4. The survey results of the organic products perception of Ukrainian consumers in the market. (Developed by the author)

Respondents in the study of the organic market perception were consumers in Ukraine. The respondents were 1,000 people from 18 to 75 years old. Respondents provided an assessment of their own product perception in the percentage from $1 \%$ to $100 \%$. The main questions that were raised to the interviewees were:

1. Attitudes towards organic products - the average rating was $73.3 \%$.

2. The concept of "organic products" is identical to the concept of «natural products» $-89.3 \%$.
3. The price of organic products is always higher than the price of traditional products - $47,4 \%$.

4. The choice of exported organic products in case of necessity or other motives $-88,0 \%$.

5. The choice of Ukrainian organic products in case of need or other motives $-35,0 \%$.

6. The level of popularization of foreign organic products $-97.0 \%$.

7. The level of popularization of Ukrainian organic products $-34.6 \%$.

8. The level of culture of consumption of organic products abroad $-90.1 \%$. 
9. The level of culture of consumption of organic products in Ukraine - $37.8 \%$.

10. Willingness to increase the purchase of organic products in terms of awareness, popularization of organic products at the state level, manufacturers and other institutions $-75.7 \%$.

According to the survey, respondents assessed the level of organic market development at a high level, determined that the consumption culture of organic products abroad, the popularization level of these products from 90 to $97 \%$. According to the perception of the Ukrainian organic products, the respondents consider the problem of low demand for it is that it is higher in price than products made by traditional methods, the image of Ukrainian organics is low, the consumption culture of this product is almost absent but not popularized in Ukraine.

\section{Conclusions}

According to the analysis, it can be argued that Ukraine is a country with great opportunities for organic agricultural production. This is due to the geographical location of the state, its natural economic potential, development support and promotion of donor countries, the desire of agricultural producers to increase production volumes in the organic sector, access to the European Union (EU) markets.

But a significant problem of the slowdown in the organic segment, according to the research results, is the low perception in the domestic organic market, the lack of image support for producers and government involvement in information - advisory support and information campaign on the consumption culture of organic products.

But realities point to positive shifts. For society, the main trend is «to be healthy», the media, outdoor advertising, Internet bloggers every day offer us to do sports and eat healthy (healthy) food. This is how the opinion is formed in the consumer's mind that: health is the main element of success and an indicator of a certain wellbeing. That is why the same motives will significantly affect the increase in market demand for organic products and stimulate producers to increase its production both in the state and abroad.

\section{Bibliographic references}

Abrar, M., Baig, S., Bashir, M., Shabbir, R., \& Ayub, M. (2018). Consumer attitude and purchase intention towards organic textile products. Amazonia Investiga, 7(17), 472-485. Retrieved from https://amazoniainvestiga.info/index.php/amazo nia/article/view/762

Act of Ukraine № 425-VII. «About the production and turnover of organic agricultural products and raw materials» was adopted on September 3, 2013.

Blackwell, R., Miniard, P., J. \& Engel, J. (2007) Consumer Behavior. St. Petersburg: 10 th Ed. Federation of Organic Movement in Ukraine (2020). Organic in Ukraine. Retrieved from: http://organic.com.ua/organic-v-ukraini.

Government Portal (2020). Ukraine ranked first in Europe in volume of imported organic products and second in the world. Retrieved from: https://www.kmu.gov.ua/news/ukrayinaposila-pershe-misce-v-yevropi-za-obsyagamiimportovanoyi-organichnoyi-produkciyi-tadruge-u-sviti.

Granovska, V. (2017) Prospects for the development of the organic market in Ukraine. Economics of the Agroindustrial Complex. 4, 31-40.

Hot Agricultural Policy (2020). Named the top 10 countries-importers of Ukrainian organic products. Retrieved from: https://agropolit.com/news/17429-nazvano-top10-krayin-importeriv-ukrayinskoyi-

organichnoyi-produktsiyi

Information and analytical portal of the agroindustrial complex of Ukraine (2021). Organic production in Ukraine. Retrieved from: https:

//agro.me.gov.ua/ua/napryamki/organichnevirobnictvo/organichne-virobnictvo-v-ukrayini. Kaminska, A. (2020). World experience of organic production development. Agromir. 1718, 23-27.

Maruszewski, G., \& Hickman, D. (2017). Green business for small and medium enterprises. Kiev. Milovanov, E. (2018). Regional support for organic agricultural production in the world. Scientific Bulletin of Uzhgorod University. 2 (52), 63-74

Mowen, J., \& Minor, M., (1998) Consume Behavior. 5th ed. New Jersey: Prentice Hall inc. Oleksenko, R., Kolokolchykova, I., \& Syzonenko, O. (2019). Ukraine in the Context of the World Organic Production of Agricultural Products. Modern Development Paths of Agricultural Production. Springer. Cham. (Scopus), pp. 507-514

Ostapenko, R., Herasymenko, Y., Nitsenko, V., Koliadenko, S., Balezentis, T., \& Streimikiene, D. (2020). Analysis of Production and Sales of Organic Products in Ukrainian Agricultural Enterprises. Sustainability, 12(8), 3416. 
Ponomarov, S. (2019) Eco-production is profitable. Agronegocios. Retrieved from: http://agro-business.com.ua/agro/ideitrendy/item/13377-ekovyrobnytstvo-tsevyhidno.html

Pyrozhok, O. (2019) Who in Ukraine produces real organic products. Verdad económica. Retrieved from: https://www.epravda.com.ua/publications/2019/ 04/3/646613/

Shkuratov, A., Chudovska, V., \& Vdovichenko, A. (2015). Organic Agriculture: Environmental and economic imperatives for development: a monograph. Kiev: DIA, $246 \mathrm{c}$.

Turyansky, A., Merenkov, I., Dobrunova, A., Prostenko, A., \& Oliva, L. (2018). State support improvement for ecological land-use in terms of transition to rural territory sustainable development. Amazonia Investiga, 7(15), 13-19.
Retrieved

from https://amazoniainvestiga.info/index.php/amazo nia/article/view/373

Willer, H., \& Lernoud, J. (2019). The world of organic agriculture. Statistics and emerging trends 2019. FAO (pp. 1-336).

Willer, H., Lernoud, J., \& Kemper, L. (2018) The World of Organic Agriculture 2018: Summary. Statistics , Summary. FiBL \& IFOAM Organics International. Retrieved from: https://orgprints.org/id/eprint/34674/1/willeretal-2018-world-of-organic-summary.pdf Willer, H., Lernoud, J., Schlatter, B., Travnicek, J., \& Kemper, L. (2020) The World of Organic Agriculture 2020. Organic World. Retrieved from:

https://orgprints.org/id/eprint/37222/9/willer-etal-2020-full-document-2020-02-28-4thcorrigenda.pdf 